population health is the central criterion of sustainability. Our prime, anthropocentric reason for seeking social stability, a congenial and safe urban environment, and the maintenance of nature's life-support systems is to ensure the protection and improvement of human wellbeing, health and survival.

\section{References}

1. Eckersley R. Is modern Western culture a health hazard? Int $J$ Epidemiol 2006; 35: 252-8. doi:10.1093/ije/dyi235

2. Finer SE. The life and times of Sir Edwin Chadwick. London: Methuen and Co., 1952.

3. McCalman J. 'All just melted with heat': mothers, babies and 'hot winds' in colonial Melbourne. In: Sherratt T, Griffiths T, Robin L, editors, A change in the weather. Canberra: National Museum of Australia Press, 2005, p. 114.

4. Cumpston J. Health and disease in Australia, Lewis MJ, editor. Canberra: AGPS, 1989, p. 108.
5. Kessel A. Air and public health. Cambridge: Cambridge University Press, 2005, p. 56.

6. Howard E. To-morrow: a peaceful path to real reform, 1898. Republished London: Routledge, 2003.

7. Awofeso N. The Healthy Cities approach - reflections on a framework for improving global health. Bull World Health Organ 2003; 81(3): 222-3.

8. Stephens C. Healthy cities or unhealthy islands? The health and social implications of urban inequality. Environ Urban 1996; 8: 9-30. doi:10.1177/095624789600800211

9. House of Representatives Standing Committee on Environment and Heritage. Sustainable cities 2025. Canberra: The Parliament of the Commonwealth of Australia, 2005.

10. McMichael AJ. Chapter 9. In: Human frontiers, environments and disease: past patterns, uncertain futures. Cambridge: Cambridge University Press, 2001.

\title{
Developing a national approach to building healthy and sustainable cities
}

\section{Renate T. Howe}

School of History and Heritage Society, Deakin University. Email:renate.howe@deakin.edu.au

\begin{abstract}
Effective strategies to build a national approach to the integration of health and urban planning at all levels of government is essential if the health problems of urban Australians, such as obesity and respiratory illnesses, are to improve. This paper examines some policies and initiatives that could facilitate intergovernment cooperation on health and sustainability within the constraints of Australia's federal government system. These include recommendations for an Australian Sustainability Commission and Charter of Sustainability, evaluations of the Better Cities Program of the 1990s, and current proposals for improving urban governance to enable the implementation of a healthy and sustainable cities agenda.
\end{abstract}

Health is not generally perceived as an urban planning issue although 'many of today's health problems are embedded physically and culturally in the ways that we build and inhabit our cities. ${ }^{11}$ In Australia's federal system of government, urban planning requires coordination between three levels of government (national, state and local); $;^{2,3}$ however, there has been limited effort over the past decade to promote a coordinated national response to urban issues. This paper examines some emerging governance strategies to facilitate the better integration of health and urban planning in Australian cities.

\section{Australian House of Representatives inquiry into sustainable cities}

A recent development has been the appointment, with bipartisan support, of a House of Representatives Standing Committee to inquire into sustainable cities. In 2005, the inquiry produced the Sustainable Cities Report, ${ }^{4}$ recommending: the establishment of an Australian Sustainability Commission to monitor progress in cities; the appointment of a Sustainability Commissioner; and the development of a Charter of Sustainability. The possibility of identifying and including health objectives in a charter is an encouraging starting point, although there has been little evidence of high-level political support from the Australian Government for implementation of the Charter's recommendations.

Submissions received by the committee encouraged them to revisit the Better Cities Program (1991-96) as a model for intergovernmental cooperation in the planning and 
management of urban development. Using an area strategy approach, the Better Cities Program encouraged innovative project management techniques and objectives for improving the quality of life..$^{5-7}$ A National Cities Program, similar to the Better Cities Program, was suggested by some submissions. Although the Sustainable Cities Report concluded that there was a clear case for leadership in the development of national urban policy, a major weakness of its recommendations was the lack of financial incentives for the development of a coordinated intergovernment approach through the proposed Australian Sustainability Commission.

\section{Facilitating intergovernment cooperation in urban issues}

Intergovernment cooperation is under consideration by the Local Government and Planning Ministers' Council in response to a proposal for a National Program on Sustainable Communities that was prepared in 2004 by major stakeholders (the Planning Institute of Australia, Property Council of Australia, the Planning Officials Group and the Royal Australian Institute of Architects). The National Action Plan based on the proposal comprises: seven propositions related to a shared vision; a national plan of action; urban action plans; a sustainable communities commission; a national sustainable communities fund; performance indicators; and sustainable regulation.

At the request of the Council of Australian Governments, a Development Assessment Forum was established in 1998, including all levels of government and national stakeholder bodies, to develop a way for the different state planning systems to achieve agreed outcomes. So far these outcomes have focused on achieving efficiency in the regulation of land use development and have not addressed broader social or health issues. ${ }^{8}$ However, the Development Assessment Forum indicates the possibilities of initiating cooperative approaches between different levels of government and stakeholders that foster more long-term strategic planning, enabling the integration of health objectives.

\section{Lessons from the Better Cities Program}

An effective national approach for urban health and planning requires more than these cautious attempts at coordination and falls short of the combination of national leadership, shared funding and an area strategy focus which was used effectively in the Better Cities Program. Evaluations of the Better Cities Program identified that the area strategy approach facilitated a focus on placebased needs. Area strategies, which encouraged social interaction, especially in the planning of public spaces, were found to have contributed to well-being and security. ${ }^{9}$ The Better Cities Program also demonstrated the importance of focusing on outcomes to overcome fragmentation in governance:
It showed that if we could overcome the political divisions between departments, between structures we could then overcome the kind of segmented way we think, to think more laterally. If we could look more at the outcomes we wanted to achieve than the inputs the governments find so difficult to drum up, then we would be able to do much more creative, worthwhile things. ${ }^{10}$

\section{Lessons from the United Kingdom}

It is hard to see a commitment in Australia to the scale of intervention needed for a national program for sustainable and healthy communities. Certainly there is nothing equivalent to the United Kingdom Government's Sustainable Communities Plan of 2003, an impressive and comprehensive plan backed by $£ 38$ million of commitments addressing housing, infrastructure, regional growth, homelessness, environmental improvement, urban renewal, planning system reform and related economic, social welfare, health and educational changes. ${ }^{11}$

\section{Transport and housing policy}

Essential underpinning for healthy and sustainable cities is transport and housing policy. The Department of Transport and Regional Services program, Aus Link, was a promising model of national infrastructure provision but focused on road transport not urban public transport. At the state level, infrastructure planning and development is usually undertaken under public-private partnerships, which are driven by efficiency objectives. There has been little consideration of health and sustainability implications in larger transport projects, which usually by-pass ordinary land use planning policies and procedures. ${ }^{12}$ In relation to housing policy, the Australian Government, states and territories cannot agree on the development of a national housing strategy. This has contributed to ad hoc coastal residential development and poorly designed and sited metropolitan greenfields developments. More dense development in the inner and middle suburbs of our larger cities has been poorly integrated with health objectives.

National leadership and commitment is essential for a sustainable and healthy cities agenda. An assessment by Lyndsay Nielson (former secretary of the Department of Sustainability and Environment in Victoria) of the implementation of the Melbourne 2030 strategy has noted that most states have developed sophisticated urban strategies in the absence of 'any articulated national framework of policy'. ${ }^{13}$ While from a national perspective there is consistency between the state policies, these need a federal urban policy framework and funding to be effective. For example, the more dense activity centres integral to Melbourne 2030 need federal support for the necessary public transport infrastructure to be successful. 


\section{Improving urban governance}

A national planning approach also depends on wellresourced institutions to run our cities. The Planning Institute of Australia is urging the establishment of Metropolitan or Sustainability Commissions within cities to achieve coordination and policy focus. ${ }^{14}$ Marcus Spiller, past president of the Institute, believes that state and local government cooperation is too difficult to achieve in urban planning, citing obstructive and parochial local governments as the reason. ${ }^{15}$ The Institute is lobbying for Metropolitan Commissions that would be democratically elected and representative of the city as a whole rather than local municipalities, to restore 'long-termism' to metropolitan strategic planning and overcome the present fragmentation of decision-making. Spiller argues that although Metropolitan Commissions introduce a new tier of government they are the type of metropolitan institutions needed to implement a sustainability agenda.

More feasible are Development Corporations and Redevelopment Authorities that have been used for specific projects, for example at Ultimo-Pyrmont and Redfern in Sydney, the East Perth Redevelopment Authority (all Better Cities projects) and the Docklands Redevelopment Authority in Melbourne. A model for key transit cities and activity centres under Melbourne 2030 has been introduced in the outer suburban City of Dandenong, where the Minister for Planning has been deemed the planning authority responsible for social and economic development, with the Dandenong Council and the Dandenong Development Board acting in an advisory capacity. Although the role of local government within these models has been contentious, the authorities have the potential to insert health objectives into local and regional planning.

While governance changes are essential to achieve sustainable cities there are a range of other initiatives that can integrate health outcomes in planning decision-making. Courses in planning are recognising the need to train a new generation of planners with a stronger understanding of the connections between health and sustainability. A small but important step towards mainstreaming health issues into the planning system has been the appointment of a part-time health planner at Planning Institute of Australia's Victorian branch. The planner is financed by Vic Health and The Cancer Council Victoria and the planner's brief is to integrate the enabling of healthy, active life styles into planning decision making.

\section{Conclusion}

If Australia is to have sustainable cities, "more innovative and visionary thinking among leaders of the key organizations and associations - public and private - that are significant players in metropolitan development' is required. ${ }^{16}$ While little progress has been made over the past decade, developments such as the Sustainable Cities Report, the possibilities presented by the initiatives of the Council of Australian Government, and the focus on improving urban governance are encouraging. Recent political awareness of the urgent need for sustainable development and of endemic environmental urban health problems could mobilise the political support needed for health issues to be part of moves towards sustainable urban planning.

\section{References}

1. McMichael T. Opening remarks and welcome. In: Urbanism, Environment and Health, Fenner Conference; 2006 May 25-26; Canberra, Australia.

2. Fletcher $\mathrm{C}$, Walsh $\mathrm{C}$, editors. The impact of federalism on metropolitan strategies in Australia. Canberra: Federalism Research Centre, Australian National University, 1992.

3. Wright B. Expectations of a better world: planning Australian communities. Canberra: Royal Australian Planning Institute, 2001.

4. House of Representatives Environment and Heritage Committee. Sustainable cities report, August 2005. Available at http://www.aph.gov.au/house/committee/environ/ cities/report.htm [Verified 3 April 2007].

5. Howe B. Reflecting on better cities. Australian Planner 2001; 38(1): 38-44.

6. Australian National Audit Office. Building better cities. Canberra: October 1996.

7. Victoria Auditor General. Building better cities - a joint government approach to urban development, Special Report No 45; Melbourne: 1996.

8. Australian Government Department of Transport and Regional Services. A leading practice model for development assessment. Canberra: Commonwealth of Australia, 2006. Available at http://www.daf.gov.au [Verified 3 April 2007].

9. Gerner RP. Urban design and the better cities program: the influence of urban design on the outcomes of the program [thesis]. Sydney: University of Sydney; 2002. p. 70-293.

10. Howe B. The role of the national government in Building Better Cities, 1991-1996. In: Dawkins J and Searle G, editors. Australia's better cities, University of Technology papers on planning, No 9. Sydney: University of Sydney, December 1996; p. 22.

11. Office of the Deputy Prime Minister. Sustainable communities plan. London: HMSO, February 2003.

12. Stilwell F, Jordan K. In the public interest: an investigation of the pitfalls of PPPs. Arena Magazine 2004; 72: 9-12.

13. Neilson L. Managing urban change: the need for diversity and choice in housing and urban development. 12th Annual Oswald Barnett Oration, Melbourne, October 2005; pp. 15-18.

14. Planning Institute of Australia. Liveable communities: how the Commonwealth can foster sustainable cities and regions. Canberra: February 2004.

15. Spiller M. Rebuilding our metropolitan planning institutions. Australian Planner 2005; 42(3): 14-5.

16. Newton P. Urban Australia 2001. Australian Planner 2002; 39(1): 37-45. 